\title{
THE UNIVERSAL DECLARATION OF ANIMAL WeLFARE
}

\section{MIAH GIBSON*}

Animal law is gaining momentum in Australia and internationally. Initiatives such as the Universal Declaration on Animal Welfare (UDAW) attempt to secure international legal recognition for the principles of animal welfare. The extent to which they do so, however, is a matter of debate, and the subject of this article. Part II of this article outlines the development of the UDAW and current support for it. Part III compares the $U D A W$ to other animal rights/welfare declarations. Part IV describes the animal welfare legislative and policy framework in Australia, and critically examines the impact that the UDAW would have in Australia.

\section{INTRODUCTION}

The present situation [in relation to international animal law] leaves much to be desired. Certainly, the need exists for a truly global instrument with effective enforcement procedures.

\section{J Bowman, Connecticut Journal of International Law ${ }^{1}$}

Many countries have laws, regulations, codes and strategies in place that aim to protect and promote animal welfare. The New Zealand Animal Welfare and International Trade Strategy, ${ }^{2}$ the Australian Animal Welfare Strategy ${ }^{3}$ and

* BA (Media and Communications), University of Melbourne; Juris Doctor candidate, Australian National University.

1 M J Bowman, 'The Protection of Animals under International Law' (1988-1989) 4 Connecticut Journal of International Law 487, 496.

2 Sara Goff, 'Animal Welfare and International Trade Strategy' (2007) 79 Biosecurity 6, 6 $<$ http://www.biosecurity.govt.nz/files/publications/biosecurity-magazine/issue-79/biosecurity79.pdf $>$.

${ }^{3}$ Department of Agriculture, Fisheries and Forestry (Cth), The Australian Animal Welfare Strategy (Revised Edition, June 2008) <http://www.daff.gov.au/animal-plant-health/ welfare/aaws>. 
Animal Welfare Action Kenya (AWAKE) ${ }^{4}$ are just a few examples. Currently, however, there is no global agreement or treaty to protect the welfare of animals, despite the fact that billions of animals live in appalling conditions every day of their lives, ${ }^{5}$ and the treatment of animals is increasingly the subject of interest and debate in the media and the broader community, at least in the western world. ${ }^{6}$

According to the World Society for the Protection of Animals (WSPA), the Universal Declaration on Animal Welfare (UDAW) is an attempt to secure international legal recognition for the principles of animal welfare. ${ }^{7}$ It is an 'agreement among people and nations to recognise that animals are sentient and can suffer, to respect their welfare needs, and to end animal cruelty - for good. $^{, 8}$

It could be argued that the WSPA's objectives are unrealistic, and perhaps even misdirected. Some believe that in failing to alter the existing 'property' status of animals and to recognise that animals have rights of their own, efforts such as the UDAW are 'worthless'. ${ }^{9}$ In addition, when compared to other declarations, the language of the UDAW is aspirational and vague, which further undermines its capacity to generate real improvements in animal welfare. Lastly, as a Declaration, it is by nature non-binding and will not force states to take any real action to improve the treatment of animals.

This article will explore these arguments, ultimately concluding that the UDAW will not end animal cruelty, as it will not force states to enact laws that raise standards of animal welfare. It may, however, drive improvements in the treatment of animals through setting a benchmark to assist countries to develop animal welfare legislation, encouraging the comparison of animal welfare laws and policies between countries, and, if it gained sufficient acceptance, perhaps one day leading to the introduction of a Convention or Covenant on animal welfare that would contain legally binding provisions.

\footnotetext{
4 KENDAT, Animal Welfare Action Kenya (2008) AWAKE <http://www.kendat.org/ partnerships/link.php?id=34>.

${ }^{5}$ Peter Singer, Animal Liberation (Pimlico, $2^{\text {nd }}$ ed, 1995).

${ }^{6}$ Clive Phillips, The Welfare of Animals - the Silent Majority (Springer, 2009) vol 1, 60.

${ }^{7}$ Michael C Appleby and Lorna Sherwood, 'Animal Welfare Matters to Animals, People and the Environment: the Case for a Universal Declaration on Animal Welfare' (Lobby Brochure, WSPA, 2007) <http://s3.amazonaws.com/media.animalsmatter.org/files/resource_files/ original/UDAW\%20lobby\%20brochure.pdf?1314005757>.

${ }^{8}$ Ibid.

${ }^{9}$ Email from Gary L Francione to Miah Gibson, 21 April 2009.
} 


\section{The Universal Declaration on Animal Welfare}

\section{A Development of the UDAW}

The UDAW campaign has been led by the World Society for the Protection of Animals (WSPA). The WSPA describes itself as the world's largest alliance of animal welfare organisations and states that it has 850 member societies in more than 150 countries and 400000 individual supporters. It is the only animal welfare organisation to have consultative status at the United Nations (UN) and observer status at the Council of Europe. ${ }^{10}$

The WSPA claims to have prepared the first draft of the UDAW and unveiled it at the Animals 2000 World Congress held in London from 16-17 June $2000 .{ }^{11}$ Some argue that this draft was actually drawn from a failed Universal Declaration on Animal Rights that had been prepared some years earlier. ${ }^{12}$

The Animals 2000 World Congress was followed by an Intergovernmental Conference on Animal Welfare in Manila in March 2003, which was attended by 21 governmental delegations representing 19 countries. ${ }^{13}$ This conference resulted in a redraft of the UDAW. The new draft made specific mention of the 'Five Freedoms' of animal welfare: freedom from hunger, thirst and malnutrition; freedom from physical and thermal discomfort; freedom from pain, injury and disease; freedom from fear and distress and freedom to express normal patterns of behaviour ${ }^{14}$, as well as the 'Three R's' relating to the use of animals in science: reduction in numbers of animals being used; refinement of experimental methods and replacement of animals with nonanimal techniques'. ${ }^{15}$

\footnotetext{
${ }^{10}$ WSPA, Who we are, <http://www.wspa.org.au/whoarewe/Default.aspx>

${ }^{11}$ Ibid.

${ }^{12}$ The Editor, 'Compromise \& the Universal Declaration on Animal Welfare', Animal People (United States), July/August 2005, 3.

${ }^{13}$ Attendees at the conference were Australia, Bangladesh, Cambodia, China, Czech Republic, Egypt, Germany, India, Indonesia, Israel, Italy, Netherlands, New Zealand, Singapore, Switzerland, Spain, Philippines, Thailand and the United Kingdom. The United States, the European Council and Saipan were observers.

${ }^{14}$ This concept was first voiced in 1967 by the Farm Animal Welfare Advisory Committee, formed by the British government after public outcry in Britain in response to Ruth Harrison's publication Animal Machines in 1964; see above n 10.

${ }^{15}$ The 'Three R's' were first articulated in 1959 by British authors William Russell and Rex Burch; see Appleby and Sherwood, above n 7.
} 
After this came a meeting of a five-nation Steering Committee held in San Jose from 24-25 November 2005. The Steering Committee comprised the governments of Kenya, India, Costa Rica, the Czech Republic and the Republic of the Philippines. This forum also generated amendments to the text of the Declaration. The current draft of the Declaration is at Appendix $1 .{ }^{16}$

The WSPA now acts as the secretariat for the Steering Committee. The Committee aims to gain official status for the UDAW within the UN and eventually convert it into a convention on animal welfare. According to the WSPA the next steps towards achieving ratification of the Declaration at the United Nations are to:

1. Provide a petition supporting the UDAW (called 'Animals Matter to Me') to the UN;

2. Achieve governmental consensus on the final text of the UDAW;

3. Table the UDAW at the UN Economic and Social Council (ECOSOC), and then

4. Table the ECOSOC-approved Declaration before the UN General Assembly. ${ }^{17}$

\section{B Support for the UDAW}

The current text of the UDAW has been endorsed at several high level forums. The Islamic Conference on Animal Welfare, held in Cairo from 18-19 October 2008, formally accepted it. ${ }^{18}$ On 10 November 2008, the Group of $77^{19}$ hosted an ambassadorial-level briefing by the WSPA on the Declaration at the UN headquarters in New York. On 23 March 2009, the Council of the European Union invited its member states to 'support, in

\footnotetext{
${ }^{16}$ The draft of the UDAW provided in this article was current at the time of writing, however, some minor amendments were made at end of 2011. See <http://www.animalsmatter. org/en/campaign_resources/>.

${ }^{17}$ WSPA, 'The Value of Declarations' (Information Sheet, 2008) $2<\mathrm{http}: / / \mathrm{s} 3$.amazonaws.com/ media.animalsmatter.org/files/resource_files/original/Value\%20of\%20Declarations.pdf?1314 005633>.

${ }^{18}$ Peter Davies, 'Work of Non-Governmental Organisations supporting the implementation of the OIE standards' (Speech delivered to the Second OIE Global Conference on Animal Welfare, Cairo, 21 October 2008).

19 The Group of 77 (G-77) was established on 15 June 1964 by 77 developing countries. It currently includes 130 countries and provides a means for to articulate and promote collective economic interest and enhance their joint negotiating capacity.
} 
principle, the UDAW initiative in the relevant international fora' ${ }^{20}$ Some 43 governments have indicated their support for the UDAW. ${ }^{21}$

The UDAW has also had considerable support from animal welfare organisations - more than 270 of them in 78 different countries have endorsed it. ${ }^{22}$ The World Organisation for Animal Health, the World Veterinary Association, the Commonwealth Veterinary Association and the Federation of Veterinarians of Europe have officially stated their support ${ }^{23}$ and organisations including the International Fund for Animal Welfare, the American Society for the Prevention of Cruelty to Animals, Humane Society International, the Royal Society for the Prevention of Cruelty to Animals and Compassion in World Farming, have become key partners in the UDAW campaign. ${ }^{24}$

The UDAW campaign has been met with much enthusiasm from the general public. A petition in support of the UDAW called 'Animals Matter to $\mathrm{Me}^{\text {,25 }}$ was launched in June 2006 and received 1 million electronic signatures in 18 months. At the time of writing this number was 2.2 million - still well short of the WSPA's goal of 10 million. ${ }^{26}$ The WSPA has also created a function for supporters to automatically 'post' their support for the UDAW on online social networks such as Facebook and Twitter. ${ }^{27}$ Overall, the UDAW has received more support than any other international animal welfare initiative. ${ }^{28}$

\section{THE IMPACT OF THE UDAW}

There has been little debate in academic circles about what impact the UDAW will have on the treatment of animals in countries that adopt it. Most of the

\footnotetext{
${ }^{20}$ Council of the European Union, 'Council Conclusions on a Universal Declaration on Animal Welfare' (Press Release, 6430/09, 13 February 2009) 3.

${ }^{21}$ Email from WSPA, Animal Welfare Link - Issue 17, disseminated via email on 28 February 2011.

${ }^{22}$ Who we are, above $\mathrm{n} 10$.

${ }^{23}$ Ibid.

${ }^{24} \mathrm{Ibid}$.

${ }^{25}$ WSPA, Animals Matter To Me (2009) <http://www.animalsmatter.org/>.

${ }^{26}$ Peter Davies, '10 million signatures - Animals Matter To Me Campaign' (Speech delivered at the WSPA Symposium, London, 8 June 2006).

${ }^{27}$ See $<$ http://www.wspa.org.au/wspaswork/udaw/Default.aspx $>$.

${ }^{28}$ Appleby and Sherwood, above $\mathrm{n} 7$.
} 
articles about the UDAW have been written by the WSPA and its supporters, so naturally they have focussed on its benefits. ${ }^{29}$

It is possible, however, to draw some inferences about the potential impact of the Declaration by examining its focus on 'animal welfare', as opposed to 'animal rights'. Animal rights theorists, such as renowned US legal academic Gary Francione, would argue that the fact that the Declaration promotes animal welfare, rather than animal rights, means that it will do nothing to reduce the incidence of animal exploitation or cruelty. ${ }^{30}$ Animal welfare supporters such as US legal academic and Vice President/Chief Counsel for Animal Protection Litigation at The Humane Society of the United States, Jonathan Lovvorn, would counter that we do not need to recognise the individual 'rights' of animals in order to make meaningful improvements in the treatment of animals and reduce the incidence of animal cruelty. ${ }^{31}$ These two streams of thought are considered below in the context of the UDAW.

\section{A Animal Welfare $v$ Animal Rights: Larger Cages $v$ No Cages}

As highlighted above, two distinct groups exist in the animal advocacy movement - those who argue for 'animal rights', and those who argue for 'animal welfare'. The animal rights movement (also referred to as the 'abolition' movement) sees our use of animals as the key problem, and seeks to challenge the current legal status of animals as property in order to secure fundamental rights for animals which are absolutely protected and cannot be sacrificed to a higher, 'human' need. ${ }^{32}$ Theorist and philosopher Tom Regan describes this argument as one that calls for 'no cages' for animals. ${ }^{33}$

By contrast, animal welfare supporters (also referred to as 'reformists') highlight our treatment of animals as the primary concern. They seek better regulation of animal treatment within a framework that continues to characterise animals as the property of human beings. The welfare model does not ban exploitation of animals but prescribes acceptable limits to that

\footnotetext{
${ }^{29}$ See, eg, Appleby and Sherwood, above $\mathrm{n} 7$.

${ }^{30}$ Gary L Francione, 'Animal Rights and Animal Welfare' (1996) 48 Rutgers Law Review 397.

${ }^{31}$ Jonathan R Lovvorn, 'Animal Law in Action: The Law, Public Perception, and the Limits of Animal Rights Theory as a Basis for Legal Reform' (2005-06) 12 Animal Law 133. Jonathan Lovvorn is also the Vice President of Animal Protection Litigation for the Humane Society of the United States.

32 Voiceless, What is Animal Law? (2009) <http://www.voiceless.org.au/Law/Misc/ What_is_Animal_Law_html $>$.

${ }^{33}$ Tom Regan, The Case for Animal Rights (University of California Press, $2^{\text {nd }}$ ed, 2004).
} 
exploitation by prohibiting unnecessary pain and suffering. ${ }^{34}$ Regan describes this argument as one that calls for 'larger cages' for animals. ${ }^{35}$

Animal law theorists have generally aligned themselves with one of these two approaches - advocating for an improvement in the treatment of animals within the current legal framework, or arguing that there cannot be any significant improvement in the treatment of animals, or reduction in animal cruelty, until animals are recognised as having their own inherent value, rather than existing as merely the property of human beings.

What I aim to do in this paper is consider what the UDAW will achieve for animals in the context of these two streams of thought.

\section{B What Will the UDAW Achieve from an Animal Rights Perspective?}

As a supporter of animal rights, Gary Francione advocates for an immediate end to the classification of animals as property, but he does accept that initiatives that achieve incremental change towards this goal may also be beneficial, provided that such changes result in a diminution of the property status of animals. ${ }^{36}$ An examination of the wording of the UDAW instantly reveals that it does not explicitly require signatories to put an end to the classification of animals as property. But is it possible that the UDAW could achieve an incremental change to the property status of animals in such a manner that would satisfy Francione?

In his article 'Animal Rights and Animal Welfare' ${ }^{37}$ and text Animals as Persons: Essays on the Abolition of Animal Exploitation, ${ }^{38}$ Francione provides a set of criteria for measuring whether an initiative recognises that animals have more than extrinsic or conditional value alone, and is thus an incremental step towards the abolition of the property status of animals.

\footnotetext{
${ }^{34}$ Lovvorn, above n 30.

${ }^{35}$ What is Animal Law?, above n 31.

${ }^{36}$ Appleby and Sherwood, above $\mathrm{n} 7$.

${ }^{37}$ Francione, 'Animal Rights and Animal Welfare', above n 29, 397.

38 Gary L Francione, Animals as Persons: Essays on the Abolition of Animal Exploitation (Columbia University Press, 2008).
} 
The two criteria I will focus on here are:

1. The extent to which the initiative involves prohibitions of significant institutional activities (as opposed to traditional welfarist regulations requiring 'humane' treatment within these activities); and

2. The extent to which the initiative recognises that animals have interests that are not tradable or able to be ignored merely because humans will benefit from doing so. ${ }^{39}$

The UDAW does not appear to satisfy the first criterion. It does not set out any precise standards, nor does it directly prohibit any activities that involve animals. Instead, it uses traditional 'humane treatment' language. It states that the Five Freedoms 'provide valuable guidance' on the use of animals [my emphasis] but does not impose prohibitions on treatment falling outside these freedoms. It seeks to moderate the suffering of animals, rather than petitioning against it altogether.

The UDAW does not perform well against the second criterion either. In 'acknowledging that the humane use of animals can have major benefits for humans' the Declaration implies that animal welfare initiatives should be designed with the potential impact on human interests in mind. The wording of the Declaration provides no indication that it would encourage nation states to adopt laws that protect animal interests, without regard to the advantages or disadvantages these laws would produce for human beings. Thus an assessment against Francione's criteria suggests that the UDAW would not take us any closer to recognising the inherent value of animals and, in his view, would therefore not result in any reduction in the exploitation of animals. ${ }^{40}$

Welfare advocates such as Jonathan Lovvorn would naturally disagree with this assessment, and argue that the fact that the UDAW does not alter the property status of animals does not mean that it will not achieve any meaningful benefits for animals. In his view, we should free ourselves from the 'seductive web of animal rights theory' and get to work helping animals suffering right now - which we can do through animal welfare initiatives. ${ }^{41}$

Lovvorn's argument is appealing - it gives us reason to think that the 2.2 million electronic signatures we have added to the Animals Matter to $\mathrm{Me}$

\footnotetext{
${ }^{39}$ Appleby and Sherwood, above $n 7$.

${ }^{40}$ Ibid.

${ }^{41}$ Lovvorn, above n 30, 148.
} 
petition have been worthwhile. But even if we accept that a failure to abolish the property status of animals does not render an animal protection initiative worthless, it is still unclear what benefits the UDAW will offer from a welfare perspective. Even if we accept that the UDAW will not change the fact that animals are used for human benefit, is it even going to change the way we treat them?

\section{What Will the UDAW Achieve for Animal Welfare?}

An analysis of the language used in the UDAW suggests that it is too vague to generate any significant improvements in the animal welfare laws operating in various countries in the world. The UDAW embodies 'the philosophy of animal welfare' and describes ideals rather than setting precise standards of animal welfare and imposing obligations on signatories to ensure that these standards are met. ${ }^{42}$

Declarations are notoriously vague, so in some ways it should be no surprise that the UDAW contains vague language. As former WSPA Director General Andrew Dickson pointed out when the UDAW was unveiled in June 2000, 'a Universal Declaration for the Welfare of Animals would not provide for any powers to enforce changes at national level, or sanction countries that did not conform to its principles'. ${ }^{43}$ His statement implicitly recognises that the UDAW, being a Declaration in nature, may never be as effective at driving changes in the laws and policies of states, as, for example, a Convention could be.

Accepting that the UDAW has not been designed to force changes in national animal welfare legislation, how then will it lead to positive changes in the treatment of animals around the world? The WSPA believes that we should look to the success of the Universal Declaration of Human Rights (UDHR) ${ }^{44}$ to get a sense of what the UDAW could achieve.

Since its adoption by the UN General Assembly in 1948, the UDHR has had an enormous impact on attitudes, policies and legislation in countries in all regions of the world. An examination of the language in the UDHR may provide clues as to why it has had this level of success - it is significantly more directive than the UDAW.

\footnotetext{
${ }^{42}$ Ibid; email from Verna Simpson to Miah Gibson, 20 April 2009.

${ }^{43}$ Quoted in Compromise \& the Universal Declaration on Animal Welfare, above $\mathrm{n} 12$.

${ }^{44}$ Universal Declaration on Human Rights, GA Res 217A (III), UN GAOR, 3rd sess, 183rd plen mtg, UN Doc A/810 (10 December 1948).
} 
The UDHR is made up of 30 distinct articles which set out precisely which aspect of human life they aim to protect, and suggest some means of measuring whether that aspect is being adequately protected. For example, Article 4 states that 'no one shall be held in slavery or servitude; slavery and the slave trade shall be prohibited in all their forms', Article 5 that 'no one shall be subjected to torture or to cruel, inhuman or degrading treatment or punishment' and Article 13 that 'everyone has the right to freedom of movement and residence within the borders of each state. ${ }^{45}$ The UDAW (see Appendix 1), by contrast, states that 'animals are living, sentient beings and therefore deserve due consideration and respect', and 'the welfare of animals shall be a common objective', and 'all appropriate steps shall be taken to prevent cruelty to animals and to reduce their suffering'. In addition, no definitions of 'welfare' or 'cruelty' are provided. The wording of the UDAW is feeble in comparison to that of the UDHR.

Of course, it has already been noted that the UDAW is a Declaration that focuses on welfare rather than rights, so it needs to be considered in that context. If we want to achieve the success of the UDHR, perhaps we should be directing our efforts towards developing a Universal Declaration on Animal Rights rather than Animal Welfare.

The International Animals Rights League tried just that. It developed a Universal Declaration of Animal Rights (UDAR) (see Appendix 2). Unfortunately however, the UDAR did not achieve the success its founders had hoped for.

\section{The Universal Declaration of Animal Rights and the Bill on Animal Rights}

The ascription of moral and legal rights to animals, and their enshrinement in a United Nations Declaration of Animal Rights is a logical and inevitable progression of ethical thinking. ${ }^{46}$

Uncaged 2008

The draft Universal Declaration of Animal Rights uses language much stronger and more specific than that used in the UDAW (see Appendix 2). For example, Article 8(2) of the UDAR states that 'the massacre of wild animals, and the pollution and destruction of biotypes are acts of genocide' and

\footnotetext{
${ }^{45}$ Ibid.

${ }^{46}$ Uncaged, Human and Animal Rights: One Struggle - One Fight (2008) <http://www. uncaged.co.uk/declarat.htm>.
} 
Article 9(1) that 'the specific legal status of animals and their rights must be recognized by law'.

The UDAR goes far beyond the provisions of the UDAW and imposes clear obligations on state parties. It provides for the recognition of the specific legal status of animals, which indicates an acceptance that animals have inherent rights and a rejection of their 'property' status. Such a declaration would perform better against Francione's criteria. Unfortunately, attempts to gain broad acceptance of the UDAR have not been successful.

The first draft of the UDAR was published in 1972. In the following year the National Council for the Protection of Animals in France made some amendments to it, adopted it, distributed it and collected 2 million signatures from supporters. The text was then endorsed at an international meeting held in London in 1977. On 15 October 1978, it was made public and presented to a full audience in the UNESCO House in Paris. The text was then revised in 1989 by the International League of Animal Rights and submitted to the UNESCO Director General in $1990 .^{47}$

After that, support for the UDAR waned and the draft was put on the shelf. According to the editor of Animal People, ${ }^{48}$ after a period it was dusted off, retitled, amended to dispose of any association with animal rights activism and presented by the WSPA as the new Universal Declaration on Animal Welfare. ${ }^{49}$ Others believe that the text of the UDAW was based on the Amsterdam Protocol (Appendix 4). ${ }^{50}$ In any case, the UDAR campaign came to an end without having delivered its promised improvements in the treatment of animals around the world.

Another initiative, the United States Animal Bill of Rights (Appendix 3), also failed to gain high-level support. The Bill aimed to influence the regulatory framework for animals in the United States by awarding animals certain basic legal rights. ${ }^{51}$ It was designed by the United States Animal Legal Defense Fund, which wanted 'to show Congress a groundswell of support for

\footnotetext{
${ }^{47}$ Compromise \& the Universal Declaration on Animal Welfare, above n 12; UDHR, UN Doc $\mathrm{A} / 810$.

${ }^{48}$ A US bi-monthly newspaper.

${ }^{49}$ Compromise \& the Universal Declaration on Animal Welfare, above $\mathrm{n} 12$.

50 Interview with Peter Thornber, Department of Agriculture, Fisheries and Forestry (Melbourne, 28 April 2009).

${ }^{51}$ Lovvorn, above $\mathrm{n} 30$.
} 
legislation that protects animals and recognizes that, like all sentient beings, animals are entitled to basic legal rights in our society, ${ }^{52}$

The Bill recognised the right of animals 'to be free from exploitation, cruelty, neglect and abuse' and 'to have their interests represented in court and safeguarded by the law of the land' (see Appendix 3). The provisions of the Bill were narrower in scope than those of the UDAR, but still went further than the UDAW does. Unfortunately, it also failed to gain considerable support. Just over 250000 Americans have lent their support to the Bill, but it has not become law or received recognition at any significant US legal or governmental forums. ${ }^{53}$

These examples suggest that instruments that adopt the language of 'rights' and provide strong protections for animals are unlikely to be successful. The Australian Government has given every indication that it would not support a declaration like the UDAR, by its weak attempts at introducing even basic protections for animals, such as stunning before slaughter and the banning of live exports. ${ }^{54}$ Perhaps we therefore ought to focus our attention on initiatives such as the UDAW, which has already some received international backing. Though it will not take us closer to recognition of the inherent value of animals and a removal of their 'property' status, nor force states to introduce animal welfare laws, this Declaration may produce some indirect benefits for animals.

\section{E The Benefits of the UDAW}

One of the benefits of the UDAW is that it provides a benchmark for countries to use when developing, or building upon, their own animal welfare laws. Though the UDAW does not set out precise standards for animal welfare or define cruel treatment, its provisions could be used as broad guidelines for nations that have no animal welfare legislation or policies in place.

Since it will become an 'international' agreement, the UDAW has the potential to encourage countries to share and compare their animal welfare laws and perhaps to bring weaker legislative and policy regimes more into line with stronger ones, leading to improvements in animal welfare protections. If it gained acceptance within the UN, the UDAW would be a

\footnotetext{
${ }^{52}$ Animal Legal Defense Fund, Do You Believe Animals Deserve Basic Legal Rights? (1999) $<\mathrm{http}: / /$ org2.democracyinaction.org/o/5154/t/3755/petition.jsp?petition_KEY=82>.

${ }^{53}$ Compromise \& the Universal Declaration on Animal Welfare, above n 12; Lovvorn, above n 30.

${ }^{54}$ Animals Australia, 'Live Export Vote Fails Animals and Australians' (Press Release, 18 August 2011) $<$ http://www.animalsaustralia.org/media/press_releases.php?release $=167>$.
} 
tool for applying diplomatic and moral pressure on countries without any animal protection legislation to come on board.

If the UDAW Steering Committee's hopes are realised, it could pave the way for the creation of a Convention on Animal Welfare that contains legally binding standards for the treatment of animals and holds parties who have ratified it to account in the achievement of those standards. ${ }^{55}$

The advantages flowing from the UDAW in terms of benchmark-setting would be most significant in countries which currently have no animal welfare laws or policies, and particularly in those that have never even considered introducing them. Is Australia one of those countries? What would the impact of the UDAW be on a country like Australia?

\section{THE IMPACT OF THE UDAW IN AUSTRALIA}

On the surface, Australia appears to have some of the world's most progressive legislation in protecting the health and wellbeing of animals. ${ }^{56}$ Though there are clear gaps and inconsistencies in the legislative protections afforded to animals (which will be elaborated upon below), at first glance it seems that animals in Australia would not benefit significantly from the introduction of the UDAW. Australian legal academic Steven White states that

from an Australian perspective, it is difficult to see how adoption of the Declaration would have any discernible effect on the welfare of animals, given the qualified nature of the language, and the relatively sophisticated animal welfare regime in this country. ${ }^{57}$

Dr Kevin Doyle, National Veterinary Director of the Australian Veterinary Association and a member of the Animal Welfare Strategy Advisory Committee, agrees: 'as to what it will achieve in Australia I expect this to be

\footnotetext{
55 The UDHR, for example, served as the foundation for two binding UN human rights covenants, the International Covenant on Civil and Political Rights, and the International Covenant on Economic, Social and Cultural Rights. The principles of the UDHR were also incorporated into several international treaties.

56 The Australian Animal Welfare Strategy, above n 3; email from Kevin Doyle to Miah Gibson, 24 April 2009.

${ }^{57}$ Interview with Steven White, lecturer at Griffith University (Melbourne, 15 April 2009).
} 
largely intangible but in practical terms it may also give a public and hence political foundation and put it more firmly on the national agenda. ${ }^{58}$

Others disagree with this assessment. Verna Simpson, the Director of Humane Society International (Australia) believes that the UDAW will provide 'guidance for clear objectives that would see the treatment of animals improved on both a local and international scale ${ }^{59}$ Dr Hugh Wirth, National President of the Royal Society for the Prevention of Cruelty to Animals (RSPCA), believes that the UDAW will force Australian governments to recognise the sentience of animals when drafting and implementing animal welfare legislation and policy. ${ }^{60} \mathrm{Dr}$ Wirth is a past president of the WSPA and is currently a member of the WSPA Board.

The UDAW has been publicly endorsed by Asia Pacific nations such as Fiji, Cambodia and New Zealand, yet Australia, which claims to be, and in many ways is, an 'animal welfare leader' has yet to give its official backing. ${ }^{61}$ The Australian government has given 'in-principle' support, but refuses to make a public announcement or commit to adhering to the UDAW's provisions until it has seen the final draft. It has not given a clear indication of when this is likely to occur, but suggests that it may be closer to the date when the UN passes a motion supporting the UDAW - potentially during 2011.

Even if Australia were to lend its support, as mentioned above, the principles of the UDAW would not be binding because the UDAW is a declaration, rather than a treaty. In addition, there is a risk that the Australian government would use its adoption of the UDAW as a defence to criticisms of its lack of animal welfare protections, without making any actual changes to its laws or policies. Notwithstanding this, the Australian parliament and the government would likely face some criticism in the public sphere were they to introduce new laws, codes or policies that were inconsistent with the principles of the Declaration. It is therefore worthwhile considering what the potential impact of the Declaration would be on the animal welfare laws currently in place in Australia.

\footnotetext{
${ }^{58}$ Email from Kevin Doyle to Miah Gibson, 24 April 2009.

${ }^{59}$ Email from Verna Simpson to Miah Gibson, 20 April 2009.

${ }^{60}$ Interview with Hugh Wirth, President of RSPCA Victoria (Melbourne, 27 April 2009).

${ }^{61}$ Voiceless, Animals Matter to the EU but not so much to Australia $(2009)<\mathrm{http}: / /$ www.voice less.org.au/News/Animal_Law_News/Animals_Matter_to_the_EU_but_not_so_much_to_Au stralia.html $>$ ('Animals Matter to the EU').
} 


\section{A The Animal Welfare Legislative and Policy Framework in Australia}

\section{$1 \quad$ Legislation}

The federal parliament does not have specific power to enact laws concerning animal welfare. ${ }^{62}$ It does, however, have the power to enact laws with respect to the import and export of animals and the management of wild animals, and to sign and give effect to international agreements relating to animals. ${ }^{63}$ Australian local councils oversee, and in some cases enact, laws concerning the management of companion animals and unwanted animal control. The primary legislative responsibility for animal welfare legislation rests with the Australian states and territories.

Each Australian state and territory has enacted animal protection laws that are based on the idea of preventing cruelty towards animals, and has developed mechanisms for enforcing these laws. Under these laws cruel treatment, or inflicting unnecessary pain or suffering on an animal, constitutes an offence. In New South Wales and Victoria such laws are contained within a Prevention of Cruelty to Animals Act, while in South Australia, the Australian Capital Territory, the Northern Territory, Tasmania and Western Australia they are found in an Animal Welfare Act. Queensland has enacted an Animal Care and Protection Act. $^{64}$

These Acts do not provide an exclusive definition of 'cruel' treatment though they do offer examples. Victoria's Prevention of Cruelty to Animals Act provides that 'cruelty' encompasses wounding, mutilating, torturing, overriding, overdriving, overworking, abusing, beating, worrying, tormenting or terrifying an animal, among other things. ${ }^{65}$ Queensland's Animal Care and Protection Act provides that cruel treatment includes beating an animal so as to cause it pain, abusing, terrifying, tormenting or worrying it, or treating it in a way that causes pain which 'in the circumstances, is unjustifiable,

\footnotetext{
${ }^{62}$ Australian Constitution s 51.

${ }^{63}$ Ibid ss 51(i), 51(xxix).

${ }^{64}$ See Animal Welfare Act 1992 (ACT); Prevention of Cruelty to Animals Act 1979 (NSW); Animal Welfare Act 2007 (NT); Animal Care and Protection Act 2001 (Qld); Animal Welfare Act 1985 (SA); Animal Welfare Act 1993 (Tas); Prevention of Cruelty to Animals Act 1986 (Vic); Animal Welfare Act 2002 (WA).

${ }^{65}$ Prevention of Cruelty to Animals Act 1986 (Vic) s 9.
} 
unnecessary or unreasonable'. ${ }^{66}$ No guidance on what can be considered 'unjustifiable, unnecessary or unreasonable' is provided.

\section{Codes of Practice}

The states and territories have also adopted Codes of Practice (COPs) relating to animal welfare that have been developed by the Primary Industries Ministerial Council. ${ }^{67}$ The COPs are usually based on the Model Codes of Practice (MCOPs) that provide minimum standards for animal care and specify the duty of care to be given to animals. In theory, the Codes are designed to fill some of the gaps left by the legislation. In reality, they often weaken the legislation by providing exemptions or defences to the cruel treatment of animals. For example, the COPs covering the care and use of livestock animals provide them with far less protection than non-livestock animals receive in the domestic setting. ${ }^{68}$

There are significant inconsistencies between jurisdictions in relation to the content of COPs, and the consequences flowing from conduct that breaches (or complies with) them. In relation to content, many states and territories have developed codes in the same topic area that are inconsistent with each other and with the MCOPs. In relation to applicability, compliance with codes is voluntary in every state and territory except South Australia, where breach of a Code will incur penalties. In most states and territories compliance with a Code will be a defence to prosecution under the relevant animal welfare legislation, but in NSW it is only admissible in evidence, and in Tasmania the situation is unclear. ${ }^{69}$

\section{The Australian Animal Welfare Strategy}

In response to concerns about this lack of consistency, in May 2004 the federal government launched an Australian Animal Welfare Strategy (AAWS). The strategy is being implemented by the Department of Agriculture, Fisheries and Forestry (DAFF) with oversight by the AAWS Advisory Committee. The members of the Committee include representatives from the RSPCA, the Australian Veterinary Association, the National

\footnotetext{
${ }^{66}$ Animal Care and Protection Act 2001 (Qld) s 18.

${ }^{67}$ The Primary Industries Ministerial Council is comprised of federal, state and territory primary industries ministers.

${ }^{68}$ See, eg, Code of Accepted Farming Practice for the Welfare of Cattle 2001 (Vic); Code of Practice for Sheep in Western Australia 2003 (WA).

${ }^{69}$ Animals Matter to the EU, above n 59.
} 
Consultative Committee on Animal Welfare and the University of Wollongong.

The vision of the Strategy is that 'the welfare of all animals in Australia is promoted and protected by the development and adoption of sound animal welfare standards and practice' ${ }^{70}$ It has resulted in:

1. Working groups for each of the animal sectors, which are made up of representatives from animal welfare groups and state/territory, federal and local governments;

2. Funding for a review of current legislative implementation and regulatory arrangements in Australian jurisdictions;

3. A recommendation to establish an Animal Research Centre, and

4. The splitting up of MCOPs into Australian Standards and Guidelines that will be adopted in each state and territory, thereby ensuring consistency. The Standards are regulatory (provided that states pass the requisite legislation) while the Guidelines remain unenforceable. So far this has only been accomplished for one MCOP — the Land Transport of Livestock MCOP - but progress is under way for it to be implemented for cattle and sheep MCOPs as well. ${ }^{71}$

Whether these developments will actually result in better animal welfare outcomes remains to be seen.

As this demonstrates, on the surface Australia appears to have a relatively complex and sophisticated animal welfare legal and policy framework, yet the lack of clarity and definitions in the state and territory laws, and the inconsistencies and potentially dilutive effect of the COPs, mean that Australia does not deliver strong protections for animals. Yet, even if the Australian government chose to give effect to the principles of the UDAW, this still would not result in significant improvements to these laws.

\footnotetext{
${ }^{70}$ Australian Animal Welfare Strategy, above n 3.

${ }^{71}$ Compromise \& the Universal Declaration on Animal Welfare, above n 12; email from Verna Simpson to Miah Gibson, 20 April 2009. See also Australian Animal Welfare Standards and Guidelines, Cattle (3 November 2011) Animal Health Australia <http://www.animal welfarestandards.net.au/cattle/>.
} 


\section{B The Impact of the UDAW on Australian Animal Welfare Laws}

\section{Federal Legislation}

The Australian Meat and Live-Stock Industry Act 1997 (Cth) governs the treatment of animals involved in export. Section 57A(1) of the Act states that the Minister may determine, in writing, principles relating to the export of livestock from Australia. The Australian Standards for the Export of Livestock set out the basic requirements for the conduct of the livestock export trade and include such provisions as:

Any livestock for export identified after loading as being sick or injured must be given immediate treatment; and be killed humanely and without delay, where euthanasia is necessary;

and

All livestock on the vessel must have access to adequate water of a quality to maintain good health and suitable feed to satisfy their energy requirements, taking into consideration any particular needs of the livestock species, class and age. ${ }^{72}$

The Standards have drawn criticism from the RSPCA on the grounds that they require things that are not measurable and contain loopholes that result in the exclusion of particular animals. ${ }^{73}$ The UDAW contains nothing that would answer these criticisms. In fact, there is no mention of trade in the UDAW at all, even though this is an area in which an overwhelming amount of animal suffering takes place. This may be in part because some countries, including Australia, have refused to lend their support to the UDAW if it contains any reference to trade, probably in anticipation of strong objections from those who currently profit from the live export trade. ${ }^{74}$

Even in the absence of a direct reference to trade, had the drafters of the UDAW included a provision that 'all Five Freedoms must be incorporated into any national legislation', rather than simply that 'the Five Freedoms ... provide valuable guidance for the use in animals', they may have generated real improvements in the treatment of exported animals. This is because any

\footnotetext{
${ }^{72}$ Department of Agriculture, Fisheries and Forestry (Cth), The Australian Standards for the Export of Livestock, Version 2.2, December 2008.

${ }^{73}$ RSPCA, 'Australian Livestock Export Standards - A Flawed Process' (Research Report, 2006).

${ }^{74}$ Compromise \& the Universal Declaration on Animal Welfare, above n 12.
} 
export laws and standards would thereafter need to ensure that exported animals not only had access to adequate food and water, but also that they were free to express normal patterns of behaviour - something often denied to animals in the live export trade.

The UDAW would thus result in no modification to the Australian Standards for the Export of Livestock.

\section{$2 \quad$ Local Government Laws}

The UDAW is also unlikely to result in improvements to the by-laws of local governments in Australia. Such laws relate to domestic pets, other companion animals and to the control of unwanted animals. To take one example, in the City of Greater Dandenong in Victoria a pet owner may be guilty of an offence and liable for a penalty if:

- Their dog is able to leave the owner's property of its own accord, even if the dog has not actually left the property, or

- Their animal housing is not kept clean, placed no less than $6 \mathrm{~m}$ from the frontage of the land, placed no less than $1 \mathrm{~m}$ from any boundary, and placed no less than $3 \mathrm{~m}$ from any dwelling. ${ }^{75}$

No definition of 'clean' is provided, and there is no requirement for the animal housing to be safe, comfortable or suitable for the animal. Yet again, the UDAW would not generate an improvement in these laws, as it does not prescribe that domestic animals should be treated in a manner consistent with the Five Freedoms, nor set any requirements in relation to animal shelter.

\section{State and Territory Legislation}

As discussed above, there is considerable inconsistency in the content and applicability of COPs in the various states and territories in Australia. Unfortunately, adoption of the UDAW would not tackle these inconsistencies, or otherwise strengthen the animal protections in state and territory law.

If the UDAW provided comprehensive definitions of 'cruelty' and 'unjustifiable, unnecessary or unreasonable' treatment, it could be used to fill the gaps left by the COPs. If it were more directive and specific it might generate improvement in the protections already in place in national

\footnotetext{
${ }^{75}$ City of Greater Dandenong, Laws for Animal Owners (2008) $<$ http://www.greaterdandenong. com/Documents.asp?ID=1500\&Title=Laws + for + Animal + Owners $>$.
} 
legislatures. An acknowledgement that 'many states already have a system of legal protection for animals' and encouragement for them to 'ensure the continued effectiveness of these systems and the development of better and more comprehensive animal welfare provisions' is simply not enough. The UDAW would not result in improvements to animal welfare legislation at the state and territory level.

\section{Conclusion}

As these case studies show, Australian animal welfare laws would probably not undergo any significant amendments even if the Australian government were to support the UDAW. The benefit of the UDAW in a country like Australia is perhaps only that it might generate some slight improvements to animal welfare legislation flowing from comparisons between the animal welfare laws of Australia and those of other countries. The UDAW is likely to have a greater impact in countries with no animal welfare laws in place, by providing a benchmark by which to set animal welfare laws and policies. As discussed, it will not, however, result in a change to the legislative status of animals - for the time being, we will continue to recognise them as our 'property'.

Yet in spite of its shortcomings, it may be worthwhile lending our support to this initiative. The more pressure that is put on governments to sign onto the UDAW, the more likely the goals of the Steering Committee will be realised, one day leading to the development of a Convention on Animal Welfare that contains legally binding provisions which would make a difference to the treatment of animals.

The draft of the UDAW is still under consideration and the WSPA is seeking support for it. Whether we consider ourselves animal rights activists or animal welfare advocates, clearly the time has come to act. The draft will shortly be submitted to the UN for consideration and it remains unclear what the response of the Organisation will be. So go on, sign up at www. animalsmatter.org. 


\section{APPENDIX 1}

\section{THE UNIVERSAL DECLARATION ON ANIMAL WELFARE}

INITIAL DRAFT TEXT ARISING FROM THE MANILA CONFERENCE ON ANIMAL WELFARE (2003) AND THE COSTA RICA STEERING COMMITTEE MEETING (2005) FOR MINISTERIAL CONFERENCE CONSIDERATION

\section{Preamble}

[The Costa Rica Steering Committee, following on from the Manila Conference on Animal Welfare, confirms:]

That animal welfare is an issue worth consideration by governments.

That the promotion of animal welfare requires collective action and all stakeholders and affected parties must be involved.

That work on animal welfare is a continuous process.

\section{A Proposal for a Declaration on Animal Welfare ARISING FROM THE MANILA CONFERENCE [ON ANIMAL WELfare] (MARCH 2003) AND THE CostA RICA STEERING Committee Meeting (November 2005)}

RECOGNIZING that animals are living, sentient beings and therefore deserve due consideration and respect;

RECOGNIZING that animal welfare includes animal health [and that veterinarians have an essential role in maintaining both the health and welfare of animals]; 
RECOGNIZING that humans [inhabit] this planet with other species and other forms of life and that all forms of life co-exist within an interdependent ecosystem;

RECOGNIZING the importance of the ongoing work of the OIE (World Organization for Animal Health) in setting global standards for animal welfare];

AGREEING that the term [state] includes people and civil society;

ACKNOWLEDGING that many [states] already have a system of legal protection for animals, both domestic and wild;

SEEKING to ensure the continued effectiveness of these systems and the development of better and more comprehensive animal welfare provisions;

ACKNOWLEDGING that the humane use of animals can have major benefits for humans;

AWARE that the "five freedoms (freedom from hunger, thirst and malnutrition; freedom from fear and distress; freedom from physical and thermal discomfort; freedom from pain, injury and disease; and freedom to express normal patterns of behaviour)" and the "three Rs (reduction in numbers of animals, refinement of experimental methods and replacement of animals with non-animal techniques)" provide valuable guidance for the use of animals;

RECOGNIZING that the provisions contained in this declaration do not affect the rights of any [state];

\section{Principles of the Declaration}

1. The welfare of animals shall be a common objective for all [states];

2. The standards of animal welfare attained by each [state] shall be promoted, recognized and observed by improved measures, nationally and internationally. [Whilst there are significant social, economic and cultural differences between societies, each should care for and treat animals in a humane and sustainable manner][in accordance with the principles of the Declaration]; 
3. All appropriate steps shall be taken by [states] to prevent cruelty to animals and to reduce their suffering;

4. Appropriate standards on the welfare of animals be further developed and elaborated such as, but not limited to, those governing the use and management of farm animals, companion animals, animals in scientific research, draught animals, wildlife animals and animals in recreation. 


\section{APPENDIX 2}

\section{THE UNIVERSAL DECLARATION OF ANIMAL RIGHTS}

\section{Preamble}

Considering that Life is one, all living beings having a common origin and having diversified in the course of the evolution of the species, - Considering that all living beings possess natural rights, and that any animal with a nervous system has specific rights,

Considering that the contempt for, and even the simple ignorance of, these natural rights, cause serious damage to Nature and lead men to commit crimes against animals,

Considering that the coexistence of species implies a recognition by the human species of the right of other animal species to live,

Considering that the respect of animals by humans is inseparable from the respect of men for each other,

It is hereby proclaimed that:

\section{Article 1}

All animals have equal rights to exist within the context of biological equilibrium. This equality of rights does not overshadow the diversity of species and of individuals.

Article 2

All animal life has the right to be respected. 


\section{Article 3}

1. Animals must not be subjected to bad treatments or to cruel acts.

2. If it is necessary to kill an animal, it must be instantaneous, painless and cause no apprehension.

3. A dead animal must be treated with decency.

\section{Article 4}

1. Wild animals have the right to live and to reproduce in freedom in their own natural environment.

2. The prolonged deprivation of the freedom of wild animals, hunting and fishing practised as a pastime, as well as any use of wild animals for reasons that are not vital, are contrary to this fundamental right.

\section{Article 5}

1. Any animal which is dependent on man has the right to proper sustenance and care.

2. It must under no circumstances be abandoned or killed unjustifiably.

3. All forms of breeding and uses of the animal must respect the physiology and behaviour specific to the species.

4. Exhibitions, shows and films involving animals must also respect their dignity and must not include any violence whatsoever.

Article 6

1. Experiments on animals entailing physical or psychological suffering violate the rights of animals.

2. Replacement methods must be developed and systematically implemented.

\section{Article 7}

Any act unnecessary involving the death of an animal, and any decision leading to such an act, constitute a crime against life. 


\section{Article 8}

1. Any act compromising the survival of a wild species and any decision leading to such an act are tantamount to genocide, that is to say, a crime against the species.

2. The massacre of wild animals, and the pollution and destruction of biotopes are acts of genocide.

Article 9

1. The specific legal status of animals and their rights must be recognised by law.

2. The protection and safety of animals must be represented at the level of Governmental organizations.

Article 10

Educational and schooling authorities must ensure that citizens learn from childhood to observe, understand and respect animals.

The Universal Declaration of Animal Rights was solemnly proclaimed in Paris on 15 October 1978 at the UNESCO headquarters.

The text, revised by the International League of Animal Rights in 1989, was submitted to the UNESCO Director General in 1990 and made public that same year. 


\section{APPENDIX 3}

\section{THE ANIMAL BILL OF RIGHTS UNITED STATES OF AMERICA}

Deprived of legal protection, animals are defenseless against exploitation and abuse by humans. Through the Animal Bill of Rights, the Animal Legal Defense Fund is working to show Congress a groundswell of support for legislation that protects animals and recognizes that, like all sentient beings, animals are entitled to basic legal rights in our society.

More than a quarter-million Americans have already signed the Animal Legal Defense Fund's Animal Bill of Rights. Sign on your support and speak out to your lawmakers today!

\section{A Petition to the United States Congress}

I, the undersigned American citizen, believe that animals, like all sentient beings, are entitled to basic legal rights in our society. Deprived of legal protection, animals are defenseless against exploitation and abuse by humans. As no such rights now exist, I urge you to pass legislation in support of the following basic rights for animals:

The Right of animals to be free from exploitation, cruelty, neglect, and abuse.

The Right of laboratory animals not to be used in cruel or unnecessary experiments.

The Right of farm animals to an environment that satisfies their basic physical and psychological needs.

The Right of companion animals to a healthy diet, protective shelter, and adequate medical care.

The Right of wildlife to a natural habitat, ecologically sufficient to a normal existence and self-sustaining species population. 
The Right of animals to have their interests represented in court and safeguarded by the law of the land. 


\section{APPENDIX 4}

\section{The Amsterdam Protocol}

THE HIGH CONTRACTING PARTIES,

DESIRING to ensure improved protection and respect for the welfare of animals as sentient beings,

HAVE AGREED UPON the following provision which shall be annexed to the Treaty establishing the European Community,

In formulating and implementing the Community's agriculture, transport, internal market and research policies, the Community and the Member States shall pay full regard to the welfare requirements of animals, while respecting the legislative or administrative provisions and customs of the Member States relating in particular to religious rites, cultural traditions and regional heritage. 